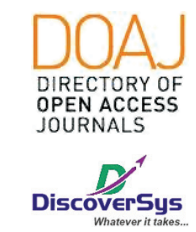

Published by DiscoverSys

\title{
Uji efektivitas ekstrak air daun ubi jalar ungu (Ipomoea batatas) terhadap profil lipid tikus putih jantan galur wistar yang diinduksi pakan dislipidemia
}

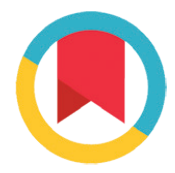

CrossMark

\author{
I Pande Putu Deny Heriwijaya, ${ }^{1 *}$ I Made Jawi, ${ }^{2}$ Bagus Komang Satriyasa ${ }^{2}$
}

\section{ABSTRACT}

Background: The conventional drugs for dyslipidemia theraphy needed to be concerned in the usage because of the side effect of the drugs. The Anthocyanin was one of the flavonoid compound that can be used as an alternative theraphy for dyslipidemia. The leaf of the purple sweet potato have been proved containing anthocyanin.

Aim: The study aims to know the effectivity of the sweet potato leaf on lipid profile of male wistar rats induced by dyslipidemia feed extract. Method: The study design was pre and post-test control group design. Thirty white male rats were divided into five groups. All of the groups were given high-cholesterol diet for three months. Negative control groups of rats were given only high-cholesterol diet alone, positive control groups were given dyslipidemia drugs and the treatment groups were given sweet potato leaf water extract with the doses of each group were $3 c c, 6 c c$ and $9 c c$. Before and after treatment, lipid profile levels were measured.

Results: There was a decrease in total cholesterol, triglyseride and LDL in treatmen group with $6 \mathrm{cc}$ and $9 \mathrm{cc}$ dose significantly $(\mathrm{p}<0,05)$ compared with the negative control group.

Conclusion: The sweet potato leaf extract can improve the lipid profile of the dyslipidemia rats.
'Program Studi Pendidikan Dokter, Fakultas Kedokteran Universitas Udayana

${ }^{2}$ Bagian Farmakologi Fakultas Kedokteran Universitas Udayana

${ }^{*}$ Correspondence to:

I Pande Putu Deny Heriwijaya,

Program Studi Pendidikan Dokter, Fakultas Kedokteran Universitas Udayana

dheriwijaya@gmail.com

Diterima: 14-08-2019

Disetujui: 09-09-2019

Diterbitkan: 01-08-2020

Keyword: dyslipidemia, anthocyanin, purple sweet potato leaf

Cite This Article: Heriwijaya, I.P.P.D., Jawi, I.M., Satriyasa, B.K. 2020. Uji efektivitas ekstrak air daun ubi jalar ungu (Ipomoea batatas) terhadap profil lipid tikus putih jantan galur wistar yang diinduksi pakan dislipidemia. Intisari Sains Medis 11(2): 452-456. D01: 10.15562/ism.v11i2.584

\section{ABSTRAK}

Latar Belakang: Obat konvensional yang biasa dipakai untuk terapi dari dislipidemia masih harus diperhatikan dalam pemakaiannya karena masih adanya efek samping yang tidak diinginkan. Senyawa antosianin merupakan salah satu senyawa flavonoid yang dapat berpotensi sebagai terapi alternatif untuk dislipidemia. Pada daun ubi jalar ungu terbukti terdapat senyawa antosianin yang dapat digunakan sebagi terapi alternatif dislipidemia.

Tujuan: untuk mengetahui efektivitas dari ekstrak daun ubi jalar ungu (Ipomoea batatas) terhadap profil lipid tikus putih jantan galur wistar yang diinduksi pakan dislipidemia.

Metode: Rancangan penelitian adalah pre and post-test control group design. Penelitian dilakukan pada 30 ekor tikus putih jantan yang dibagi menjadi lima kelompok. Kelima kelompok tikus diberi makanan tinggi kolesterol selama tiga bulan. Pada kelompok tikus kontrol negatif hanya diberi pakan kolesterol, kontrol positif diberikan juga obat dislipidemia dan tiga kelompok perlakuan diberikan ekstrak air daun ubi ungu dengan dosis masing-masing kelompok $3 c c, 6 c c$ dan $9 c c$. Sebelum dan setelah mendapat perlakuan dilakukan pengukuran profil lipid.

Hasil: Terdapat penurunan pada kolesterol total, trigliserida dan LDL pada kelompok perlakuan dengan dosis $6 c c$ dan 9cc secara signifikan $(p<0,05)$ dibandingkan dengan kontrol negatif.

Kesimpulan: Pemberian ekstrak air daun ubi jalar ungu dapat memperbaiki profil lipid tikus dislipidemia.

Kata kunci: dislipidemia, antosianin, daun ubi jalar ungu

Cite Pasal Ini: Heriwijaya, I.P.P.D., Jawi, I.M., Satriyasa, B.K. 2020. Uji efektivitas ekstrak air daun ubi jalar ungu (Ipomoea batatas) terhadap profil lipid tikus putih jantan galur wistar yang diinduksi pakan dislipidemia. Intisari Sains Medis 11(2): 452-456. D0I: 10.15562/ism.v11i2.584

\section{PENDAHULUAN}

Penyakit kardiovaskuler adalah salah satu yang menjadi salah satu penyebab utama kematian seseorang hampir di seluruh dunia, terutama di negara-negara berkembang. Tingkat kematian yang terjadi akibat penyakit kardiovaskular terutama di
Negara-negara berkembang adalah sekitar 30\% dari semua kasus kematian. ${ }^{1,2}$ Di Indonesia, prevalensi dari penyakit stroke berdasarkan riset kesehatan dasar (Riskesdas) pada tahun 2007 adalah delapan per seribu penduduk atau sebesar $0,8 \%$. Sedangkan 
untuk penyakit jantung coroner berdasarkan riset kesehatan dasar (Riskesdas) tahun 2013 angka prevalensinya adalah sebesar $1,5 \% .^{3}$ Beberapa penelitian dilakukan dengan tujuan untuk dapat mencegah perkembangan penyakit ini. Salah satu cara yang dilakukan adalah dengan mencegah faktor-faktor resiko yang dapat mempengaruhi perkembangan dari penyakit kardiovaskular. ${ }^{2}$

Salah satu factor resiko dari terjadinya penyakit kardiovaskular adalah dislipidemia. Dislipidemia adalah keadaan dimana terjadinya peningkatan ataupun penurunan fraksi lipid dalam darah karena adanya suatu kelainan metabolisme dari lipid itu sendiri. Fraksi lipid yang mengalami kelainan biasanya adalah kenaikan kadar kolesterol total, trigliserida, kolesterol LDL dan penurunan dari kolesterol HDL. ${ }^{3}$

Berdasarkan faktor resiko terjadinya penyakit kardiovaskuler tersebut, pengobatan yang sedang dikembangkan saat ini terfokus untuk dapat menurunkan fraksi lipid dalam darah terutama menurunkan kadar kolesterol LDL dan dengan menaikkan kadar kolesterol HDL.,4 Antosianin merupakan salah satu senyawa flavonoid yang dapat berfungsi sebagai antioksidan untuk mengatasi radikal-radikal bebas dalam darah sehingga dapat digunakan untuk terapi untuk beberapa penyakit. Antosianin juga terbukti dapat digunakan untuk terapi dislipidemia, terutama untuk menurunkan kadar trigliserida dan kolesterol LDL serta meningkatkan kadar kolesterol HDL., ${ }^{4,5}$, Senyawa ini dapat bekerja dengan berbagai mekanisme, beberapa di antaranya adalah dengan menginhibisi kerja dari TNF- $\alpha$ dan pembentukan molekul-molekul adesi seperti MCP-1, ICAM-1, dan VCAM-1 yang berperan dalam proses inflamasi dan senyawa ini juga dapat bekerja sebagai antioksidan. ${ }^{7}$

Senyawa antosianin dapat ditemukan dalam tanaman ataupun buah-buahan yang memiliki warna mencolok seperti warna merah dan ungu. Ubi ungu adalah salah satu jenis umbi-umbian yang kaya akan senyawa antosianin. Penyebaran ubi ungu di Indonesia pun sangat banyak sehingga bisa didapatkan hampir di setiap daerah di Indonesia. Selain pada ubi ungu itu sendiri, pada daun dari tanaman ubi ungu ternyata juga mengandung senyawa antosianin yang cukup tinggi. Selain itu daun ubi ungu lebih mudah didapat karena ubi ungu hanya bisa dipanen beberapa kali dalam setahun sedangkan daunnya bisa diambil terus menerus. ${ }^{5,6}$ Sebelumnya sudah terdapat penelitian mengenai penggunaan ekstrak daun ubi ungu sebagai hipolipidemik, namun belum terdapat penelitian yang menggunakan pembanding seperti obat anti hiperlipidemia konvensional dan dengan variasi dosis dari ekstrak ubi ungu sendiri. Berdasarkan latar belakang tersebut peneliti ingin meneliti efektivitas dari ekstrak air daun ubi jalar ungu dengan menggunakan beberapa dosis dan dibandingkan dengan obat konvensional yang sudah ada untuk mengatahui tingkat efektivitas dari ekstrak tersebut.

\section{METODE}

Penelitian ini merupakan penelitian eksperimental menggunakan ekstrak air daun ubi jalar ungu (Ipomoeabatatas) dengan metode True Experimental Pre and Post Test Control Group Design. Penelitian ini menggunakan 5 perlakuan yaitu kontrol positif (simvastatin $0.2 \mathrm{mg}$ ), kontrol negatif (aquades), ekstrak air daun ubi jalar ungu dosis $3 \mathrm{cc}, 6 \mathrm{cc}$ dan 9cc. Penelitian dilakukan pada bulan Februari 2017, dimulai dengan proses pembuatan ekstrak air daun ubi jalar ungu di rumah peneliti dan larutan simvastatin di Laboratorium Farmakologi Fakultas Kedokteran Universitas Udayana.

Alat yang digunakan adalah kompor, panci, penggerus, stamper, gelas ukur $100 \mathrm{ml}$, spuit, timbangan, sonde lambung. Bahan yang digunakan adalah ekstrak air daun ubi jalar ungu, aquades, simvastatin $10 \mathrm{mg}$ dan pakan hiperlipidemik. Penelitian diawali dengan proses persiapan dari ekstrak air daun ubi jalar ungu. Satu kilogram daun ubi jalar ungu yang telah didapat dari Desa Langan, Tabanan dicuci bersih kemudian digerus kemudian dicampur dengan 1 liter air dan disaring. Setelah itu air hasil saringan dipanaskan sampai mendidih selama 10 menit lalu didinginkan. Setelah itu dilanjutkan dengan menyiapkan larutan simvastatin dengan menggerus simvastatin $10 \mathrm{mg}$ dan dilarutkan dengan $100 \mathrm{ml}$ pelarut.

Dilanjutkan dengan mengelompokkan subjek penelitian menjadi 5 kelompok perlakuan dengan masing-masing kelompok berisi 6 ekor tikus sebagai subjek penelitian. Kelompok I sebagai kontrol positif (simvastatin $2 \mathrm{cc} / 0.2 \mathrm{mg}$ ), kelompok II sebagai kontrol negatif (aquades), kelompok III sebagai perlakuan dosis $3 \mathrm{cc}$, kelompok IV sebagai perlakuan dosis $6 \mathrm{cc}$ dan kelompok $\mathrm{V}$ sebagai perlakuan dosis 9cc. Subjek penelitian diberi pakan hiperlipidemik selama 2 minggu lalu diambil darahnya untuk pemeriksaan profil lipid pre-test. Lalu dilanjutkan dengan pemberian pakan hiperlipidemik ditambah dengan perlakuan selama 12 minggu lalu diambil lagi darahnya untuk pemeriksaan profil lipid post-test.

\section{HASIL}

Hasil penelitian yang meliputi hasil pemeriksaan profil lipid dalam darah yaitu kolesterol total, kolesterol LDL, kolesterol HDL dan trigliserida 
dari sampel penelitian sebelum (pre-test) dan setelah (post-test) diberi perlakuan ditunjukkan pada Grafik 1, 2, 3 dan 4. Pada Gambar 1 menunjukkan perbandingan variabel kolesterol total pre

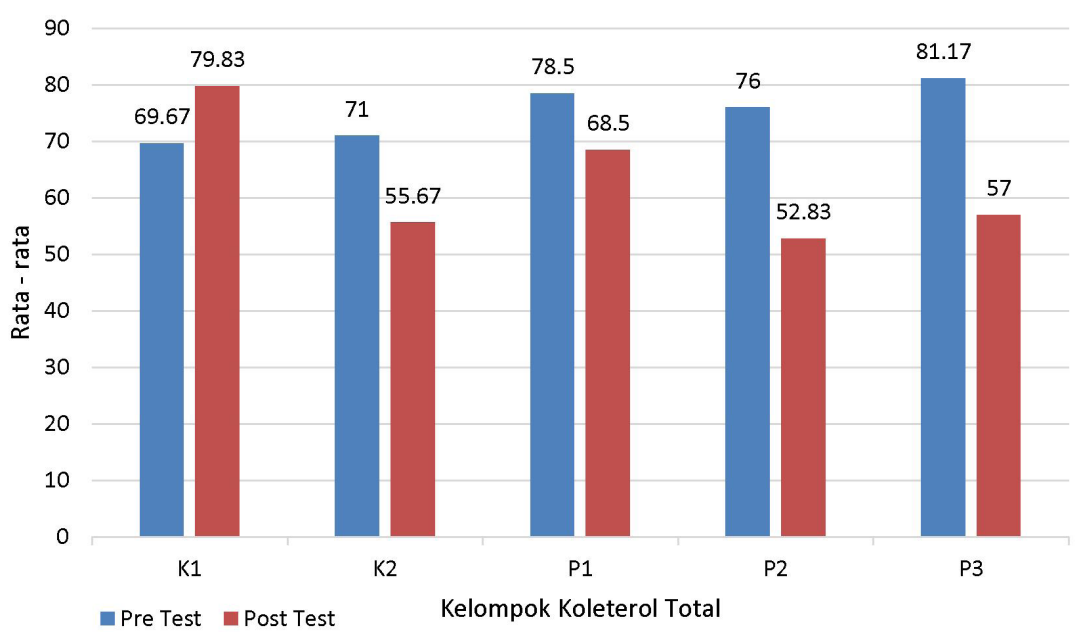

Gambar 1 Hasil pemeriksaaan kolesterol total

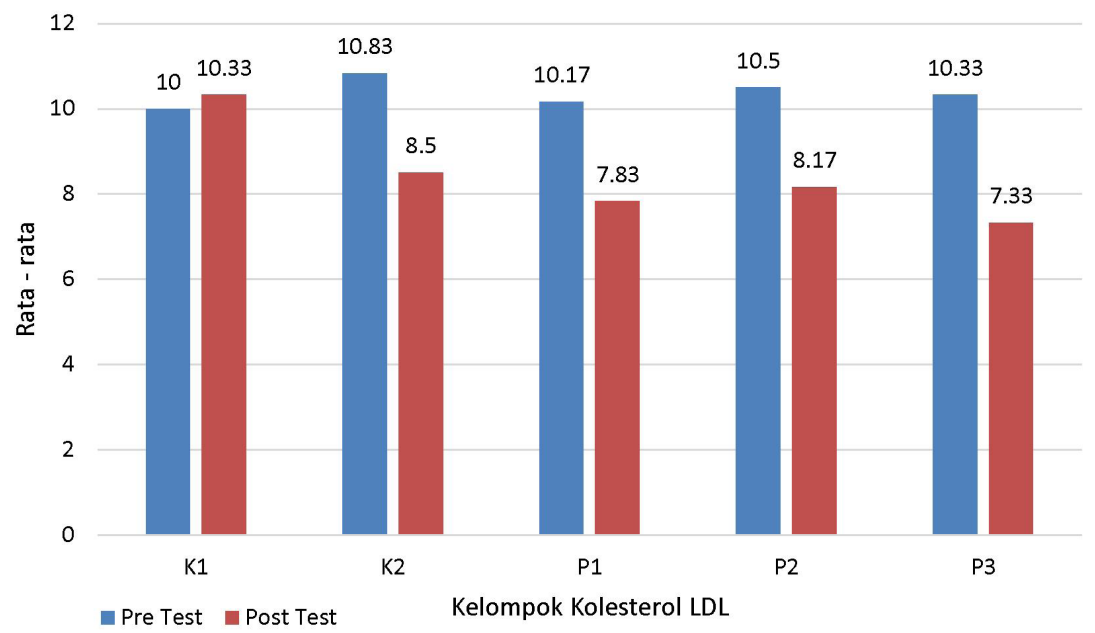

Gambar 2 Hasil pemeriksaaan kolesterol LDL

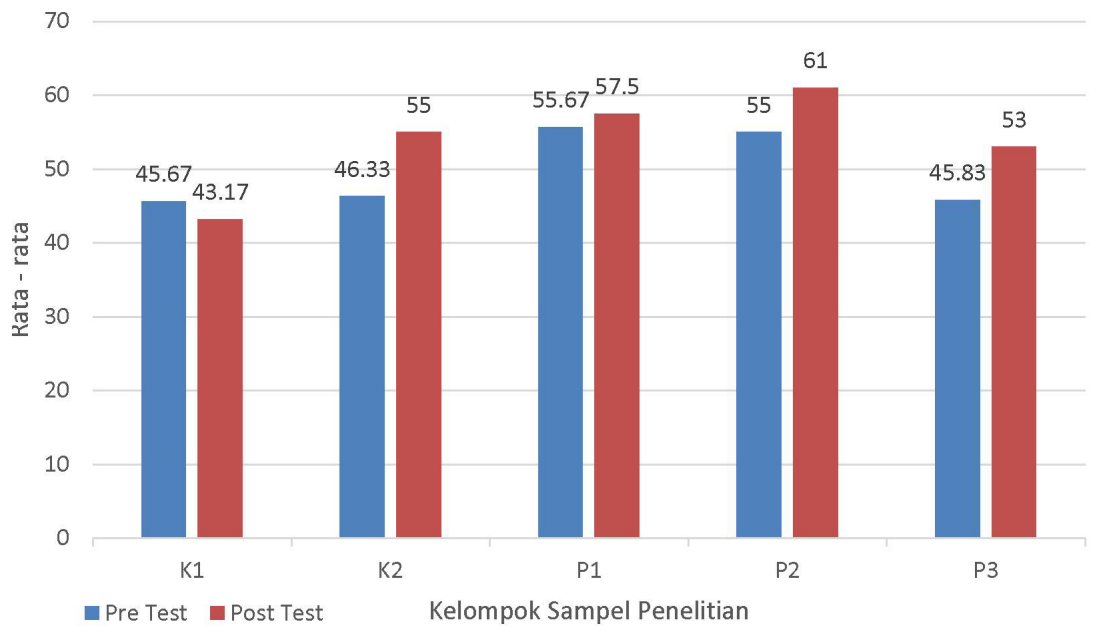

Gambar 3 Hasil pemeriksaaan kolesterol HD dan post pada sampel. Pada kelompok perlakuan K1 (kontrol negatif), terjadi peningkatan kolesterol total, namun tidak signifikan $(\mathrm{p}=0,122)$. Pada kelompok perlakuan K2 (kontrol positif), terjadi penurunan dari kolesterol total secara signifikan $(\mathrm{p}=0,012)$. Pada kelompok perlakuan P1 (perlakuan dosis I), terjadi penurunan dari kolesterol total, namun tidak signifikan $(\mathrm{p}=0,086)$. Pada kelompok perlakuan P2 (perlakuan dosis II), terjadi penurunan dari kolesterol total secara signifikan $(\mathrm{p}=0,006)$. Pada kelompok P3 (perlakuan dosis III), terjadi penurunan dari kolesterol total secara signifikan $(\mathrm{p}=0,002)$.

Pada Gambar 2 menunjukkan perbandingan variabel kolesterol LDL pre dan post pada sampel. Pada kelompok perlakuan K1 (kontrol negatif), terjadi peningkatan dari trigliserida, namun tidak signifikan $(\mathrm{p}=0,567)$. Pada kelompok perlakuan K2 (kontrol positif), terjadi penurunan dari trigliserida secara signifikan $(p=0,002)$. Pada kelompok perlakuan P1 (perlakuan dosis I), terjadi penurunan dari trigliserida secara signifikan $(\mathrm{p}=0,005)$. Pada kelompok perlakuan P2 (perlakuan dosis II), terjadi penurunan dari trigliserida secara signifikan $(\mathrm{p}=0,004)$. Pada kelompok perlakuan P3 (perlakuan dosis III), terjadi penurunan dari trigliserida secara signifkan $(\mathrm{p}=0,005)$.

Pada Gambar 3 menunjukkan perbandingan variabel kolesterol HDL pre dan post pada sampel. Pada kelompok perlakuan K1 (kontrol negatif), terjadi penurunan dari kolesterol HDL, namun tidak signifikan $(\mathrm{p}=0,642)$. Pada kelompok perlakuan K2 (kontrol positif), terjadi peningkatan dari kolesterol HDL secara signifikan $(p=0,041)$. Pada kelompok perlakuan P1 (perlakuan dosis I), terjadi peningkatan dari Kolesterol HDL, namun tidak signifikan $(\mathrm{p}=0,261)$. Pada kelompok perlakuan P2 (perlakuan dosis II), terjadi peningkatan dari kolesterol HDL, namun tidak signifikan $(\mathrm{p}=0,072)$. Pada kelompok perlakuan P3 (perlakuan dosis III), terjadi peningkatan kolesterol HDL, namun tidak signifikan $(\mathrm{p}=0,140)$.

Pada Gambar 4 menunjukkan perbandingan variabel Trigliserida pre dan post pada sampel. Pada kelompok perlakuan K1 (kontrol negatif), terjadi peningkatan dari kolesterol LDL, namun tidak signifikan $(\mathrm{p}=0,872)$. Pada kelompok perlakuan K2 (kontrol positif), terjadi penurunan dari kolesterol LDL, namun tidak signifikan secara statistik $(\mathrm{p}=0,312)$. Pada kelompok perlakuan P1 (perlakuan dosis I), terjadi penurunan dari Kolesterol LDL, namun tidak signifikan $(\mathrm{p}=0,146)$. Pada kelompok perlakuan P2 (perlakuan dosis II), terjadi penurunan dari kolesterol LDL secara signifikan $(\mathrm{p}=0,028)$. Pada kelomopok perlakuan P3 (perlakuan dosis III), terjadi penurunan kolesterol LDL secara signifikan $(\mathrm{p}=0,007)$. 


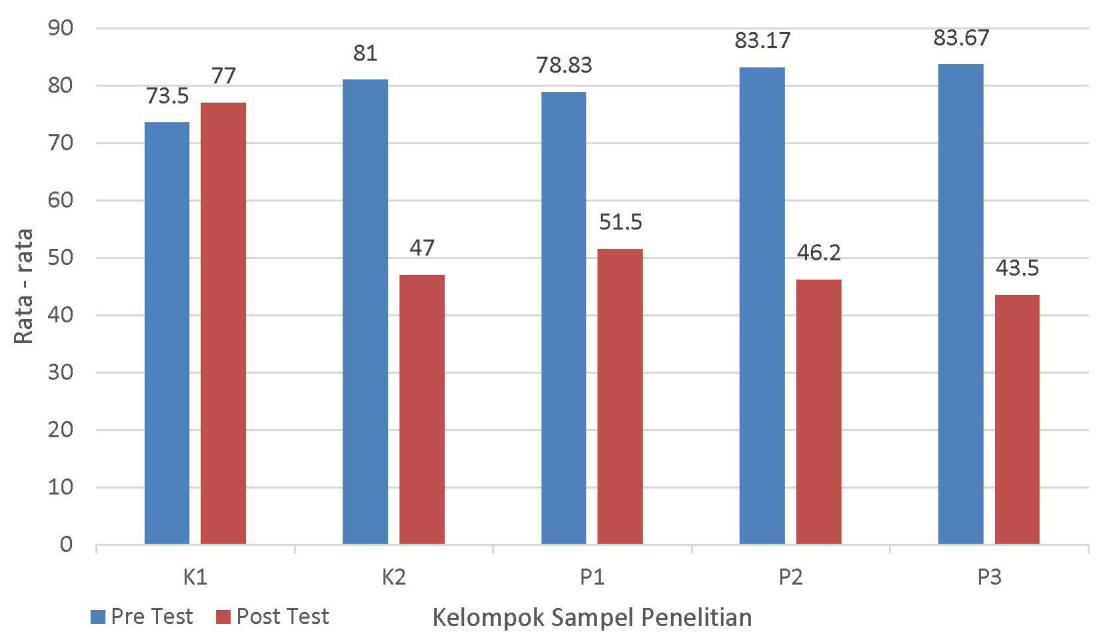

Gambar 4 Hasil pemeriksaaan trigeliserida

\section{DISKUSI}

Hasil penelitian ini menunjukkan bahwa ekstrak air daun ubi ungu memiliki efek untuk memperbaiki kadar profil lipid darah pada sampel. Pada variabel kolesterol total, kolesterol LDL dan trigliserida terjadi penurunan kadar kolesterol setelah mendapatkan perlakuan, sedangkan pada variabel kolesterol HDL terjadi peningkatan kadar dari kolesterol HDL. Disini terlihat peran dari ekstrak daun ubi ungu ini sebagai hipolipidemik atau sebagai pengontrol dari profil lipid agar tetap dalam batasan yang normal. Kandungan dari senyawa flavonoid antosianin yang cukup tinggi di dalam daun ubi ungu mampu memberikan efek untuk memperbaiki kadar profil lipid darah yaitu menurunkan kolesterol total, LDL dan trigliserida serta meningkatkan kolesterol HDL., ${ }^{4,7}$ Hal ini terjadi sesuai dengan teori yang ada, yaitu dengan meningkatkan proses eksresi dari sterol sehingga dapat menurunkan kadar kolesterol total, peningkatan receptor LDL dan kolesterol pada feses yang juga dapat menurunkan kadar kolesterol LDL dalam plasma. Selanjutnya senyawa ini dapat menghambat ekspresi dari HMG-CoA reductase yang dihasilkan di hati yang dimana HMG-CoA reductase ini berperan penting dalam proses sintesis dari kolesterol. ${ }^{4}$ Selain itu senyawa antosianin juga memiliki fungsi sebagai antioksidan, sehingga dapat mengurangi efek dari stres oksidatif yang juga berperan dalam proses terjadinya gangguan pada sistem kardiovaskular. ${ }^{7}$

Hasil dari penelitian ini juga sesuai dengan beberapa penelitian lainnya, diantaranya adalah pada penelitian ekstrak air daun ubi jalar ungu memperbaiki profil lipid dan meningkatkan kadar SOD darah tikus yang diberi makanan tinggi kolesterol. ${ }^{8}$ Hasil dari penelitian ini juga sesuai dengan penelitian pengaruh pemberian jus daun ubi jalar (Ipomoea batatas (L.)lam) terhadap kadar kolesterol LDL tikus wistar jantan (Rattus norvegicus) yang diberi pakan tinggi lemak, disebutkan bahwa jus daun ubi jalar dapat menurunkan kolesterol LDL dari tikus dislipidemia. ${ }^{9}$ Hal ini berkaitan dengan kandungan senyawa flavonoid antosianin pada bahan yang diuji. Sesuai dengan teori, kandungan senyawa flavonoid antosianin memiliki peran sebagai antioksidan, antihipertensi, hepatoprotektif dan sebagai pengontrol profil lipid darah. ${ }^{4,7,8,10,11}$

\section{SIMPULAN}

Ekstrak air daun ubi ungu dengan dosis $3 \mathrm{cc}, 6 \mathrm{cc}$ dan $9 \mathrm{cc}$ dapat memperbaiki profil lipid darah tikus putih jantan galur wistar yang diinduksi dengan pakan hiperlipidemia.

\section{UCAPAN TERIMAKASIH}

Ucapan terimakasih diberikan kepada dosen bagian farmakologi Fakultas Kedokteran Universitas Udayana yang telah membantu dalam proses penelitian dan pembuatan jurnal ini, serta kepada pihak Litbang FK Unud atas bantuannya memberikan dana penelitian sehingga penelitian ini dapat dikerjakan sebagaimana mestinya.

\section{DAFTAR PUSTAKA}

1. Slama, FB, Hcheichi H, Chemli R, Belhadj O, Ounallah HS. The use of herbal and medicinal plants for the treatment of dyslipidemia seen by herbalists and dyslipidemic patients in the Nabeul region of Tunisia's Cap Bon. Global Advanced Research Journal of Agricultural Science. 2016; 5(1): 1-7.

2. Dessi M, Noce A, Bertucci P, Villahermosa SM, Zenobi R, Castagnola V, Addessi E, Daniele N. Atherosclerosis, Dyslipidemia, and Inflammation: The Significant Role of Polyunsaturated Fatty Acids. ISRN Inflammation; 2013.

3. PERKENI. Panduan Pengelolaan Dislipidemia Panduan Pengelolaan Dislipidemia. Perkumpulan Endokrinologi Indonesia; 2015.

4. Liu C, Sun J, Lu Y, Bo Y. Effects of Anthocyanin on Serum Lipids in Dyslipidemia Patients: A Systematic Review and Meta-Analysis. PLoS ONE. 2016; 11(9): e0162089. doi:10.1371/journal.pone.0162089.

5. Husna NE, Novita M, Rohaya S. Anthocyanins Content and Antioxidant Activity of Fresh Purple Fleshed Sweet Potato and Selected Products. Agritech. 2013; 33(3): 296-302.

6. Islam S. R : Concise Reviews / Hypotheses in Food Science Sweetpotato (Ipomoea batatas L.) Leaf: Its Potential Effect on Human Health and Nutrition. Journal of Food Sience. 2006; 71(2): 13-21.

7. Reis JF, Monteiro VVS, Gomes RS, Carmo MM, Costa GV, Ribera PC, Monteiro MC. Action mechanism and cardiovascular effect of anthocyanins: A systematic review of animal and human studies. Journal of Translational Medicine, 2016: 1-16. 
8. Sumardika IW, Jawi IM. Ekstrak air daun ubi jalar ungu memperbaiki profil lipid dan meningkatkan kadar SOD darah tikus yang diberi makanan tinggi kolesterol. Medicina. 2012; 43: 67-71.

9. Pramesti R. Pengaruh pemberian jus daun ubi jalar (Ipomoea batatas L.) terhadap kadar kolesterol LDL tikus wistar jantan (Rattus norvegicus) yang diberi pakan tinggi lemak. Journal of Nutrition College. 2014; 3(4): 706-714.

10. Dharmika, IAGW, Negara, MO, Kurniawan, Y. Hubungan obesitas sentral dengan testosterone deficiency syndrome (TDS) pada laki-laki dewasa di Denpasar tahun 2017. Bali Anatomy Journal. 2018; 1 (2): 35-38.
11. Wardana, I.N.G., Widianti, I.G.A., Wirata, G. 2018. Testosterone increases corpus cavernous smooth muscle cells in oxidative stress-induced rodents (Sprague-Dawley). Bali Medical Journal 7(2): 313-322. DOI:10.15562/bmj. v7i2.970

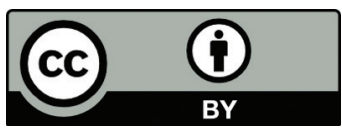

This work is licensed under a Creative Commons Attribution 